Chirurgia (2020) 115: 609-617

No. 5, September - October

Copyright@ Celsius

http://dx.doi.org/10.21614/chirurgia.115.5.609

\title{
Influence of Mesh Fixation on the Development of Postoperative Pain after Laparoscopic Inguinal Hernia Repair: A Single Surgeon Experience
}

\author{
Élthes Előd Etele, Radu Mircea Neagoe*, Dénes Márton, Daniela Sala, Árpád Török \\ $2^{\text {nd }}$ Surgery Department, Mureș County Emergency University Hospital, Târgu Mureș, România
}

*Corresponding author: Neagoe Radu Mircea, MD Professor of Surgery University of Medicine and Pharmacy $2^{\text {nd }}$ Surgery Department Mureș County University Hospital Verii Street, No. 46, Târgu Mureș Mureș, Romania

E-mail: neagoerm@gmail.com
Received: 09.12.2019 Accepted: 11.02 .2020

\section{Rezumat}

Influența metodelor de fixare a plaselor chirurgicale în apariția durerii postoperatorii în urma tratamentului laparoscopic al herniilor inghinale: Experiența unui singur chirurg

Obiective: Scopul principal al prezentului articol a fost determinarea relației dintre metodele de fixare a plaselor sintetice şi apariția durerii postoperatorii în urma tratamentului laparoscopic al herniilor inghinale.

Materiale şi metode: 101 pacienți diagnosticați cu hernie inghinală au beneficiat de tratament laparoscopic electiv al defectului parietal. Urmărirea pacienților a fost realizată la una şi trei luni după intervenția chirurgicală. Aspectele urmărite au conținut date clinice, chirurgicale şi despre senzația de durere.

Rezultate: În urma analizei multivariabile, adulți tineri (OR= 4.226; $\mathrm{p}=0.0467)$, hernia recurentă $(\mathrm{OR}=4.862 ; \mathrm{p}=0.0415)$ şi utilizarea plaselor chirurgicale necesitante de fixare $(\mathrm{OR}=4.226$; $\mathrm{p}=0.0467) \mathrm{s}$-au dovedit factori de risc independenți în dezvoltarea durerii cronice postoperatorie. În perioada de urmărire, pacienții din grupul de studiu au prezentat o durere semnificativ mai intensă (indice de durere la o lună: $S G=10,27$; $\mathrm{CG}=5,07 ; \mathrm{p}=0,0080$; indice de durere la trei luni: $\mathrm{SG}=5,02$; $\mathrm{CG}=1,42 ; \mathrm{p}=0,0406$ ). In ceea ce privește sindromul de durere cronică postoperatorie, şase pacienți din Grupul de Studiu $(12,76 \%)$, şi doar un singur pacient din Grupul de Control au prezentat după trei luni, un indice de durere mai mare de 18,5 puncte, concluzionând că fixarea plaselor sintetice creşte 
semnificativ posibilitatea sindromului de durere cronică postoperatorie $(\mathrm{p}=0,0455)$.

Concluzii: Metodele de fixare a plaselor chirurgicale în timpul tratamentului laparoscopic al herniilor inghinale, par să contribuie la dezvoltarea durerii postoperatorii cronice. Evitarea metodelor traumatizante de fixare a plaselor ar putea fi o opțiune potrivită pentru chirurgi.

Cuvinte cheie: laparoscopic, fixare de plasă chirurgicală, autoaderent, durere postoperatorie, calitate de viață

\begin{abstract}
Objective: Primary aim of the present article was to determine the relationship between mesh fixation methods and the occurrence of postoperative pain after laparoscopic inguinal hernia repair. Materials and methods: 101 patients diagnosed with inguinal hernia benefited from elective laparoscopic treatment of the abdominal wall defect. Follow up was realized at one and three months after surgical intervention. The followed details contained clinical, surgical and pain-related data.

Results: Multivariable analysis resulted young adults $(\mathrm{OR}=4.226 ; \mathrm{p}=0.0467)$, recurrent hernia $(\mathrm{OR}=4.862 ; \mathrm{p}=0.0415)$ and use of fixation requiring surgical mesh $(\mathrm{OR}=4.226 ; \mathrm{p}=0.0467)$ as significant risk factors in the development of chronic postoperative pain. During the follow up period, patients who benefitted of mesh fixation complained about significantly higher pain sensation (pain index at one month: $\mathrm{SG}=10.27 ; \mathrm{CG}=5.07 ; \mathrm{p}=0.0080$; pain index at three months: $\mathrm{SG}=5.02$; $\mathrm{CG}=1.42 ; \mathrm{p}=0.0406)$. Concerning chronic postoperative pain syndrome, six patients from SG $(12.76 \%)$ and only a single patient from CG complained after three months about pain index greater than 18.5 points, concluding that mesh fixation significantly increases the possibility of chronic postoperative pain syndrome $(\mathrm{p}=0.0455)$.

Conclusion:Mesh fixation methods during laparoscopic inguinal hernia repair seem to contribute to the development of chronic postoperative pain. Avoiding traumatizing mesh fixation methods could be a suitable option for surgeons.
\end{abstract}

Key words: laparoscopic, mesh fixation, Self-adhering, postoperative pain, life quality

\section{Introduction}

Nowadays, hernias of the abdominal wall still correspond to a major medical issue, affecting a significant part of the population. Inguinal hernias are the most common type of abdominal wall defects, representing $75 \%$ of all hernias. Laparoscopic inguinal hernia repair has been proved to be superior to the classic approach, with multiple postoperative benefits and better esthetic results. However, the complexity of the surgical procedure and the anatomy of the posterior inguinal wall, make the learning curve of these interventions steep, special training is required to acquire competency. Chronic postoperative pain following inguinal hernia repair is an unwanted and feared complication, which leads to functional limitations and diminution in the life quality of patients (1-3).

\section{Materials and Methods}

\section{Aim of Study and Patient Selection}

The present study has been started from the hypothesis that synthetic surgical mesh fixation during hernioplasty could contribute to the development of postoperative pain. Therefore, the present article aimed to determine the relationship between mesh fixation methods during TAPP procedure and development of pain in the postoperative 
period. In order to examine the mentioned data we conducted, between 01 January 2018 - 31 March 2019, a prospective case-control study at the $2^{\text {nd }}$ Department of General Surgery of Mureş County Emergency Clinical Hospital. One hundred one patients diagnosed with inguinal hernia benefited from elective laparoscopic treatment of the abdominal wall defect. All surgical interventions were performed by the same surgeon, with competency and experience in laparoscopic hernioplasty. Follow up was realized at one and three months after surgical intervention. Exclusion criteria contained the following: inguinal hernia repair in emergency conditions; complicated inguinal hernias (irreducibility, incarceration, giant inguinoscrotal hernias), other laparoscopic treatment options than TAPP procedure; open surgical techniques; patients who presented any kind of chronic pain or complained about pain sensation in the inguinal region at the time of hospital admission.

\section{Subdivision of Patients and Collected Data}

In order to achieve the formulated objective, patients were selected and divided into two groups, based on the utilization of mesh fixation, as follows: the Study Group (Patients with mesh fixation) - including 47 patients who benefitted of fastening of the surgical mesh (suture, metallic tacks, surgical glue); respectively the Control Group (Patients without mesh fixation) - including 54 patients without any fixation technique of the synthetic mesh (self-adhesive surgical mesh). All patients were carefully examined, and surgical data were gathered from medical charts and operatory protocols. Concerning the type of surgical mesh, the patients from the Study Group benefitted from simple prolene and microporous lightweight synthetic meshes, both of the above mentioned requiring fixation in order to avoid mesh migration and recurrence of the hernia. Meantime, the patients from the Control Group exclusively benefited from self-adherent surgical mesh. Regarding mesh fixation, during surgical interventions, mostly metallic tacks and surgical suture were utilized, without the necessary experience, surgical glue was applied only in a few cases. In certain instances, the prepared and retracted hernia sac was included in the continuous suture, in order to ensure proper closure of the incised peritoneum (peritoneum flap). The followed details included gender, age, location-, typeand classification of hernia, type of synthetic mesh, mesh fixation methods and presence or absence of hernia sac suture. The fixation of the hernial sac referred to suture of the prepared and retracted hernia sac while closing the incised peritoneum (peritoneum flap) which was practised at the beginning of surgery. All patients benefitted from short term follow up, under which they filled-in two pain questionnaires, at one and respectively three months after surgical treatment. Fig. 1 Pain Detect is a widely used, easy and reliable questionnaire, according to which the nature of pain, most frequent irradiation regions and also intensity of pain could be determined.

Furthermore, pain intensity was represented with a numerical scale and highlighted in the article as Pain Index. Moreover, the evaluation of pain intensity over time was also examined and highlighted during statistical analysis. Throughout the interpretation of postoperative pain, the following terms were distinguished: PP - postoperative pain, described as pain occurred after surgical intervention, which persists only for a short interval during the postoperative period; CPP - chronic postoperative pain, which represents a pain persisting for at least three months after surgery, localized at the surgical site, which was not present before surgical intervention and other causes of pain are excluded; and CPPS - chronic postoperative pain syndrome, meaning pain persisting more than three months, localized at the surgical site which was not present before surgical intervention and presenting an intensity index higher than 18.5 points.

\section{Statistical Analysis}

The collected information was processed using 


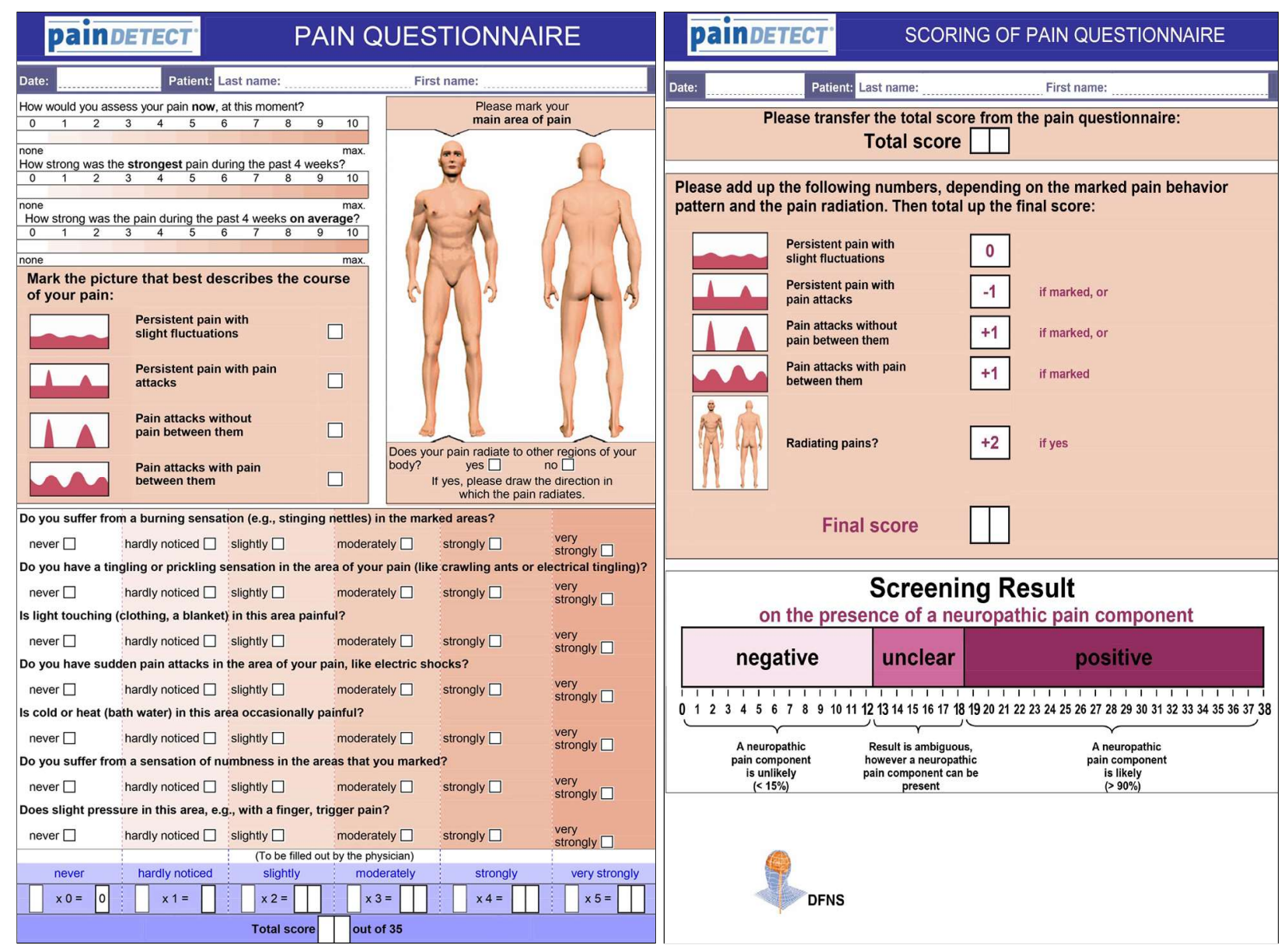

Figure 1. Pain Detect Questionnaire

Microsoft Excel. The statistical analysis of the database was performed using GraphPad InStat software (GraphPad Software, Inc., San Diego, United States of America). Quantitative variables were presented by mean and median, while qualitative and categorical variables were expressed both as integer and percentage values. A normality test was applied to all variable groups in order to determine the distribution of values. Furthermore, for the quantitative statistical analysis, Student's t-test was applied for groups with Gaussian distribution of values. At the same time, the Mann-Whitney nonparametric test was used for groups with nonGaussian distribution. Inferential statistical analysis involving odds ratios determination for the mentioned clinical, surgical and postoperative factors was performed using
Fisher's Exact Test. The level of statistical significance for the present research was set at a p-value of 0.05 , while the confidence interval was $95 \%$ for all the calculated parameters.

\section{Results}

A short interpretation of clinical and intraoperative data can be found in Table 1. All patients benefited from the minimallyinvasive treatment of the abdominal wall defect, applying exclusively laparoscopic TAPP procedure. Regarding the intraoperative classification, a predominance of external oblique parietal defects was observed in the case of both studied groups (SG-61.71\%; CG $-62.96 \%)$. Direct defects of the inguinal region rated second, while combined hernias were identified in a few cases. Multivariable analysis 
Table 1. Interpretation of clinical and surgical data

\begin{tabular}{|c|c|c|c|}
\hline & $\begin{array}{c}\text { Study Group } \\
\text { (Group with mesh fixation) } \\
n=47(\%)\end{array}$ & $\begin{array}{c}\text { Control Group } \\
\text { (Group without mesh fixation) } \\
n=54(\%)\end{array}$ & P-value \\
\hline \multicolumn{4}{|l|}{ Gender } \\
\hline Male & 43 (91.49) & $49(90.74)$ & 0.9484 \\
\hline Female & $4(8.51)$ & $5(9.26)$ & 0.9484 \\
\hline \multicolumn{4}{|l|}{ Age } \\
\hline Young adults & $13(27.66)$ & $18(33.33)$ & 0.6175 \\
\hline Middle-aged adults & 20 (42.55) & $21(38.89)$ & 0.1201 \\
\hline Elderly adults & $14(29.79)$ & $15(27.78)$ & 0.8610 \\
\hline \multicolumn{4}{|l|}{ Location of parietal defect } \\
\hline Right sided & $17(36.17)$ & $18(33.33)$ & 0.8046 \\
\hline Left sided & $20(42.55)$ & 19 (35.19) & 0.5178 \\
\hline Bilateral & $10(21.28)$ & $17(31.48)$ & 0.3663 \\
\hline \multicolumn{4}{|l|}{ Type of hernia } \\
\hline Primary hernia & 39 (82.98) & 47 (87.04) & 0.7162 \\
\hline Recurrent hernia & $8(17.02)$ & $7(12.96)$ & \\
\hline \multicolumn{4}{|l|}{ Classification of hernia } \\
\hline Direct & $15(31.91)$ & $9(16.67)$ & 0.1737 \\
\hline External oblique & $29(61.71)$ & $34(62.96)$ & 0.9141 \\
\hline Combined & $3(6.38)$ & $11(20.37)$ & 0.2083 \\
\hline \multicolumn{4}{|l|}{ Type of synthetic mesh } \\
\hline Simple prolene & $24(51.06)$ & $0(0)$ & - \\
\hline Macroporous lightweight mesh & $23(48.94)$ & $0(0)$ & - \\
\hline Self-adhering mesh & $0(0)$ & $54(100)$ & - \\
\hline \multicolumn{4}{|l|}{ Method of mesh fixation } \\
\hline Without (self-adhesive) & $0(0)$ & 54() & - \\
\hline Tacks & $30(63.83)$ & $0(0)$ & - \\
\hline Suture & $12(25.53)$ & $0(0)$ & - \\
\hline Surgical glue & $5(10.64)$ & $0(0)$ & - \\
\hline \multicolumn{4}{|l|}{ Hernia sac fixation } \\
\hline Present & $8(17.02)$ & $22(40.74)$ & 0.0363 \\
\hline Absent & 39 (82.98) & $32(59.26)$ & \\
\hline
\end{tabular}

Young adults: 18-40 years old. Middle-aged adults: 41-60 years old. Elderly adults: $>60$ years old

of the clinical and surgical aspect resulted young adults $(\mathrm{OR}=4.226 ; \mathrm{p}=0.0467)$, recurrent hernia $(\mathrm{OR}=4.862 ; \mathrm{p}=0.0415)$ and the use of fixation requiring surgical mesh $(\mathrm{OR}=4.226 ; \mathrm{p}=0.0467)$ as significant risk factors in the development of chronic pain sensation in the postoperative period.

The analyze of the filled-in questionnaires resulted in pain-related characteristics, which are described in Fig. 2 and 3. In case of both studied groups, most of the patients described their pain as persistent (SG - 58.7\%, CG - 55.56 $\%$ ), while pain attacks were present in $32.6 \%$ of cases in mesh fixation group and only $22.22 \%$ for patients included in the Control Group. Irradiation of postoperative pain was identified in a lower percentage for mesh fixation group (8.7\%) and surprisingly higher in the case of patients without mesh fastening

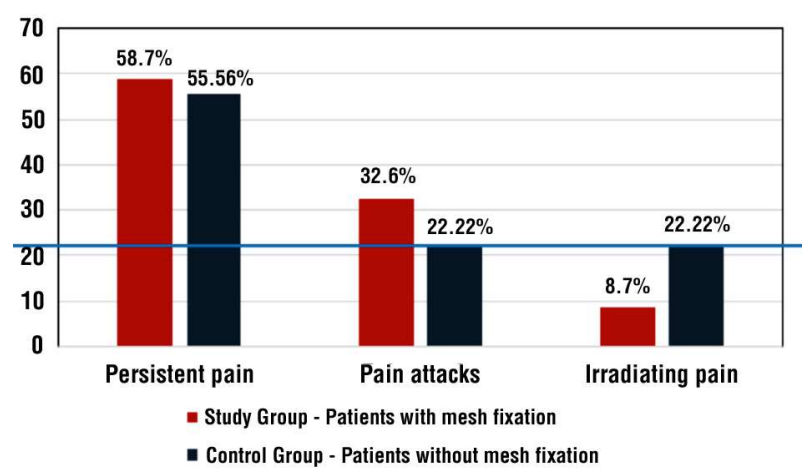

Figure 2. Nature of postoperative pain 


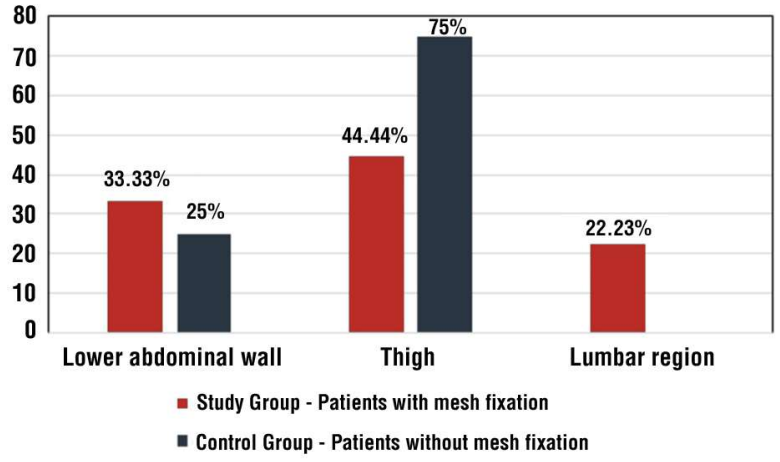

Figure 3. Irradiation regions of postoperative pain

(22.22 \%). The most frequent irradiation locations were the regions of the thigh $(75 \%)$ and lower abdomen (25\%), the pain localized in the lumbar region was described only in case of patients from Study Group (22.23 \%). The influence of mesh fixation on the occurrence of postoperative pain is presented in Table 2. One month after surgical intervention, all patients complained of a varied intensity of pain, although it has to be highlighted, that patients who benefited of mesh fixation presented significantly higher pain index $(\mathrm{SG}=10.27 ; \mathrm{CG}=5.07 ; \mathrm{p}=0.0080)$. Three months after the surgical intervention, generally fewer patients complained about the pain sensation (SG $-51.06 \%, \mathrm{CG}-31.48 \%$ ), with significantly higher presence in case of mesh fixation group ( $p=0.0472)$. During statistical analysis, the pain index for these patients also presented to be significantly higher $(\mathrm{SG}=5.02 ; \mathrm{CG}=1.42 ; \mathrm{p}=0.0406)$. The pieces of information related to changes in pain intensity during follow up are presented in

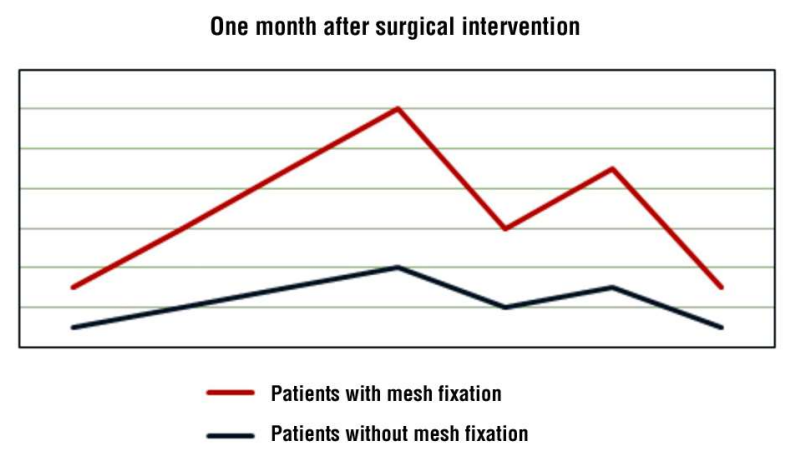

Three months after surgical intervention

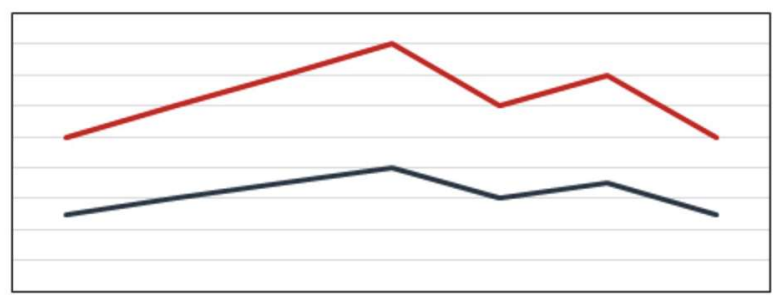

_ Patients with mesh fixation

_ Patients without mesh fixation

Figure 4. Modification of postoperative pain intensity over time

Fig. 4. Although there can be noticed a decrease in pain intensity over time, patients with mesh fixation presented a higher postoperative pain index during the whole follow up. The incidence of chronic postoperative pain syndrome is estimated in Fig. 5. A total of six patients from SG $(12.76 \%)$ and only a single patient from CG complained after three months of pain index greater than 18.5 points, concluding that mesh fixation significantly increases the possibility of chronic postoperative pain syndrome $(p=0.0455)$.

Table 2. Patients' follow-up

\begin{tabular}{lccc}
\hline & $\begin{array}{c}\text { Study Group } \\
\text { (Group with mesh fixation) } \\
\mathbf{n = 4 7 ( \% )}\end{array}$ & $\begin{array}{c}\text { Control Group } \\
\text { (Group without mesh fixation) } \\
\mathbf{n = 5 4}(\%)\end{array}$ & P-value \\
\hline $\begin{array}{l}\text { Follow up at one month } \\
\text { Presence of postoperative pain (PP) }\end{array}$ & $\begin{array}{c}\text { (100) } \\
\text { Average Pain Index }\end{array}$ & $54(100)$ & - \\
\hline Follow up at three months & 10.27 & 5.07 & 0.0080 \\
$\begin{array}{l}\text { Presence of chronic postoperative pain (CPP) } \\
\text { Average Pain Index }\end{array}$ & $24(51.06)$ & $17(31.48)$ & 0.0472 \\
\hline
\end{tabular}




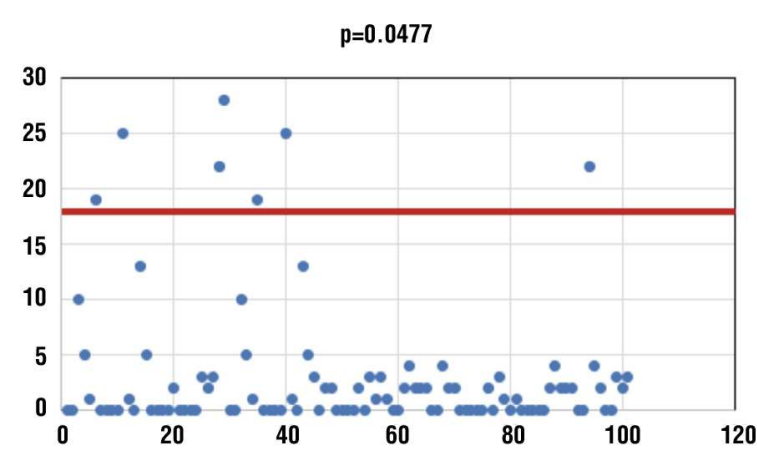

Figure 5. Incidence of chronic postoperative pain syndrome Red line = pain index greater than 18.5 points

\section{Discussion}

\section{Minimal Invasive Treatment of Inguinal Hernia}

These days, in several centres, minimally invasive treatment options of the abdominal wall defects are more preferred by surgeons than open procedures. However, in the treatment of inguinal hernia there can still be found resistance, probably due to the need of general anaesthesia, elevated costs, the difficulty of the surgical procedure and higher rate of complications associated with these procedures $(4,5)$. Furthermore, the anatomy of the posterior inguinal wall, the necessity of special training and longer learning curve confer these interventions a complexity, disliked by many general surgeons (6). However, multiple studies demonstrated the advantages of the laparoscopic approach, such as faster recovery, shorter hospitalization, better esthetic result, lower or at least similar recurrence rate, less postoperative pain $(7,8,9,10)$.

\section{Chronic Postoperative Pain}

Regarding the definition of chronic postoperative pain, there are still controversies. Some researchers define it as pain lasting at least three months after surgical intervention, but others suggest the modification of this timeframe and its extension to six months. However, it can be clearly stated that chronic postoperative pain represents a feared complication following inguinal hernioplasty. According to the literature of speciality, up to $8-16 \%$ of patients experience this kind of unpleasant sensations and depending on the degree of pain, it can have a major impact on daily activities and socio-professional reintegration. The cause of this unwanted complication is not well elucidated either. There could be several causes like the type of anesthesia, the perioperative nerve injury, mesh related complications, the inflammation process and also recurrence. However, it is multifactorial with several contributing components. However, more and more researchers state that the most important factor in the development of chronic pain is the immediate postoperative pain, and they underline the importance of postoperative pain elimination (11-13).

\section{Risk Factors in the Development of Postoperative Pain}

It is essential to be aware of the most critical risk factors that may contribute to the development of chronic postoperative pain after inguinal hernioplasty. Several studies have demonstrated that female gender, young age, the high intensity of early postoperative pain and recurrent hernias are strong risk factors, which favour the development of chronic postoperative pain (14-16). Furthermore, the use of mesh also represented the subject of many articles, highlighting that interpretation of these data is difficult due to the large variety of surgical prosthesis and their characteristics, such as weight, pore size, strength, elasticity (17). We used three types of surgical mesh for abdominal wall reconstruction, similar to those currently in use during incisional hernia repair (18): simple prolene, macroporous lightweight and self-adhering mesh. The analysis of the influence of synthetic mesh type on the development of chronic postoperative pain syndrome resulted in surgical mesh types needing fixation as an important contributor to the appearance of chronic pain. Meantime, the use of self-adherent mesh resulted in significantly less postoperative pain; an aspect which is confirmed by other authors as well 
(19-21). Surgical approach and technique also seemed to affect the development of painrelated complications. Various studies concluded minimal-invasive technique to produce less postoperative pain in comparison with the open surgical approach (22). Not least, in a recent article, Darin Correll spotlighted the importance of psychological factors (anxiety, depression) in the development of postoperative pain (23).

\section{Mesh Fixation Influencing Postoperative Pain}

Besides surgical mesh, the choice of fixation method also represents an important matter, which can influence the incidence of postoperative pain. For fastening the surgical mesh, a variety of invasive and less traumatizing methods are available. In multiple studies, glue has been demonstrated to reduce the risk of chronic pain (24-26). Meantime, Tolwer MA et al (27) and Ross SW et al (28) underlined that surgical suture or the use of metallic tacks for mesh fixation during inguinal hernioplasty increase the intensity of postoperative pain. Regarding mesh fixation, controversies still can be found in the literature of speciality. A recent Danish study which included 1421 patients undergoing TAPP repair with either fibrin glue or tacker mesh fixation, reported no significant difference concerning postoperative pain (29). Another article from the Swedish Hernia Register, including 1110 patients, compared the impact of mesh fixation on chronic pain after minimalinvasive inguinal hernia repair, resulting in no significant difference concerning chronic pain (30).

\section{Conclusion}

Avoidance of chronic postoperative pain represents a primary concern during inguinal hernia repair and may be considered one of the most important clinical outcomes. According to the present study, mesh fixation methods during laparoscopic inguinal hernia repair contribute to the development of post- operative pain. Avoiding traumatizing mesh fixation methods like suture or titanium tacks, and use of self-adhesive surgical mesh could be a suitable option for surgeons while performing laparoscopic inguinal hernioplasty. Proper management for patients who developed chronic postoperative pain is also necessary to reduce their daily suffering. Further studies with long-term follow-up are needed to confirm these results.

\section{Limitations of the Study}

The present study has several limitations, probably one of the most important of them is the relatively small sample size which caused limitations in concluding. Furthermore, with larger sample size, some of the statistical analysis would have reached significant thresholds. Secondly, a longer follow-up period is needed in order to draw important conclusions. Not least, for measuring the intensity of pain, other methods than questionnaires could be applied to serve more objective data. Overall, more extensive further studies are required in order to elucidate controversies.

\section{Ethics Approval}

For performing this study ethical approval was obtained.

\section{Conflict of Interest}

The authors declare no conflicts of interests.

\section{References}

1. Jenkins JT, O’Dwyer PJ. Inguinal hernias. BMJ. 2008; 336(638): 269-272.

2. Furtado M, Claus CMP, Totti Cavazzola L, Malcher F, Bakonyi Neto A, Saad Hossne R. Systemization of laparoscopic inguinal hernia repair (TAPP) based on a new anatomical concept: inverted y and five triangles. Arg Bras Cir Dig. 2019;32(1):e1426.

3. Manangi M, Shivashankar S, Vijayakumar A. Chronic Pain after Inguinal Hernia Repair. Int Sch Res Notices. 2014;2014:839681.

4. Neumayer L, Giobbie-Hurder A, Jonasson 0. Veterans Affairs Cooperative Studies Program 456 Investigators. Open mesh versus laparoscopic mesh repair of inguinal hernia. N Engl J Med. 2004; 350(18):1819-1827.

5. Simons MP, Aufenacker ET, Bay-Nielsen M, Bouillot JL, Campanelli $\mathrm{G}$, Conze J, et al. European Hernia Society guidelines on the treatment of inguinal hernia in adult patients. Hernia. 2009; 
13(4):343-403.

6. Claus CM, Rocha GM, Campos AC, Bonin EA, Dimbarre D, Loureiro MP, et al. Prospective, randomized and controlled study of mesh displacement after laparoscopic inguinal repair fixation versus no fixation of mesh. Surg Endosc. 2016;30(3):1134-40.

7. Bittner R, Montgomery MA, Arregui E, Bansal V, Bingener J, Bisgaard T, et al. Update of guidelines on laparoscopic (TAPP) and endoscopic (TEP) treatment of inguinal hernia (International Endohernia Society). Surg Endosc. 2015; 29(2):289-321.

8. Pedroso LM, DE-Melo RM, DA-Silva NJ Jr. Comparative study of postoperative pain between the lichtenstein and laparoscopy surgical techniques for the treatment of unilateral primary inguinal hernia. Arq Bras Cir Dig. 2017;30(3):173-176. En, Portuguese

9. Abbas AE, Abd Ellatif ME, Noaman N, Negm A, El-Morsy G, Amin, Moatamed MA. Patient-perspective quality of life after laparoscopic and open hernia repair a controlled randomized trial. Surg Endosc. 2012;26(9):2465-70.

10. Furtado M, Claus CMP, Cavazzola LT, Malcher F, Bakonyi-Neto A, Saad-Hossne R. Systemization of laparoscopic inguinal hernia repair (TAPP) based on a new anatomical concept: Inverted $Y$ and Five triangles. Arq Bras Cir Dig. 2019;32(1):e1426. En, Portuguese

11. Andresen $\mathrm{K}$, Rosenberg $\mathrm{J}$. Management of chronic pain after hernia repair. J Pain Res. 2018;11:675-681.

12. Donati M, Brancato G, Giglio A, Biondi A, Basile F, Donati A. Incidence of pain after inguinal hernia repair in the elderly. A retrospective historical cohort evaluation of 18-years' experience with a mesh \& plug inguinal hernia repair method on about 3000 patients. BMC Surg. 2013;13 Suppl 2(Suppl 2):S19. doi:10.1186/14712482-13-S2-S19

13. Manangi M, Shivashankar S, Vijayakumar A. Chronic Pain after Inguinal Hernia Repair. Int Sch Res Notices. 2014;2014:839681.

14. Bittner R, Arregui ME, Bisgaard T, Dudai M, Ferzli GS, Fitzgibbons RJ, et al. Guidelines for laparoscopic (TAPP) and endoscopic (TEP) treatment of inguinal hernia [International Endohernia Society (IEHS)]. Surg Endosc. 2011;25(9):2773-843.

15. Sevonius D, Montgomery A, Smedberg S, Sandblom G. Chronic groin pain, discomfort and physical disability after recurrent groin hernia repair: impact of anterior and posterior mesh repair. Hernia. 2016; 20(1):43-53.

16. Ergönenç T, Beyaz S, Özocak H, Palabıyık O, Altıntoprak F. Persistent postherniorrhaphy pain following inguinal hernia repair: a cross-sectional study of prevalence, pain characteristics, and effects on quality of life. Int J Surg. 2017;46:126-132.

17. Miserez M, Peeters E, Aufenacker T, Bouillot JL, Campanelli G, Conze J, et al. Update with level 1 studies of the European Hernia
Society guidelines on the treatment of inguinal hernia in adult patients. Hernia. 2014;18(2):151-63

18. Muresan M, Muresan S, Branzaniuc K, Voidazan S, Sala D, Jimborean 0 , et al. How much does decompressive laparotomy reduce the mortality rate in primary abdominal compartment syndrome? Medicine (Baltimore). 2017;96(5):e6006.

19. Quyn AJ, Weatherhead KM, Daniel T. Chronic pain after open inguinal hernia surgery: suture fixation versus self-adhesive mesh repair. L angenbecks Arch Surg. 2012; 397(8):1215-8.

20. Klobusicky P, Feyerherd P. Usage of a self-adhesive mesh in TAPP hernia repair: A prospective study based on Herniamed Register. J Minim Access Surg. 2016;12(3):226-234.

21. Tarchi P, Cosola D, Germani P, Troian M, De Manzini N. Selfadhesive mesh for Lichtenstein inguinal hernia repair. Experience of a single center. Minerva Chir. 2014;69(3):167-76.

22. Kozol R, Lange PM, Kosir M, Beleski K, Mason K, Tennenberg S, et al. A prospective, randomized study of open vs laparoscopic inguinal hernia repair. An assessment of postoperative pain. Arch Surg. 1997;132(3):292-5.

23. Correll D. Chronic postoperative pain: recent findings in understanding and management. F1000Res. 2017;6:1054.

24. Dinesh Prasad, Indira Khedkar, Mitesh Modi. Evaluation of recurrence and postoperative pain in laparoscopic inguinal hernia repair with mesh fixation versus without mesh fixation. Int Surg J. 2018; 5(4):1291-1295.

25. Andresen K, Fenger AQ, Burcharth J, Pommergaard HC, Rosenberg $J$. Mesh fixation methods and chronic pain after transabdominal preperitoneal (TAPP) inguinal hernia surgery: a comparison between fibrin sealant and tacks. Surg Endosc. 2017;31(10): 4077-4084.

26. Sun $P$, Cheng $X$, Deng $S$, Hu Q, Sun $Y$, Zheng $Q$. Mesh fixation with glue versus suture for chronic pain and recurrence in Lichtenstein inguinal hernioplasty. Cochrane Database Syst Rev. 2017;7(2): CD010814.

27. Tolver MA, Rosenberg J, Juul P, Bisgaard T. Randomized clinical trial of fibrin glue versus tacked fixation in laparoscopic groin hernia repair. Surg Endosc. 2013;27(8):2727-33.

28. Ross SW, Oommen B, Kim M, Walters AL, Augenstein VA, Heniford BT. Tacks, staples, or suture: method of peritoneal closure in laparoscopic transabdominal preperitoneal inguinal hernia repair effects early quality of life. Surg Endosc. 2015;29(7):1686-93.

29. Reinpold W. Risk factors of chronic pain after inguinal hernia repair: a systematic review. Innov Surg Sci. 2017;2(2):61-68.

30. Gutlic N, Rogmark P, Nordin P, Petersson U, Montgomery A. Impact of mesh fixation on chronic pain in total extraperitoneal inguinal hernia repair (TEP): a nationwide register-based study. Ann Surg. 2016;263(6):1199-206. 